\title{
Ecological relations and temporal changes in the pelagial of the high mountain lakes in the Rila Mountains (Bulgaria)
}

\author{
Roumen KALCHEV, Ivan BOTEV, Milena HRISTOZOVA, Wesselin NAIDENOW $\dagger$, Galerida RAIKOVA- \\ PETROVA $^{2)}$, Maya STOYNEVA ${ }^{2)}$, Dobrina TEMNISKOVA-TOPALOVA ${ }^{2)}$ and Teodora TRICHKOVA
}

Institute of Zoology, Bulgarian Academy of Sciences, 1, Tsar Osvoboditel Blvd., 1000 Sofia, Bulgaria

${ }^{2}$ University of Sofia, Faculty of Biology, 8, Dragan Tsankov Str. 1421 Sofia, Bulgaria

e-mail corresponding author: rkalchev@zoology.bas.bg

\begin{abstract}
The high mountain lakes in the Rila Mountains (Bulgaria) were studied in the years 2000 and 2001 considering the following groups of variables: geography, geology, morphology, hydrology, water chemistry of the pelagial, biomass and size structure of bacterio- phyto- and zooplankton, and occurrence of three fish species. Multivariate analysis (RDA) revealed that the nutrient concentrations in the lakes were significantly influenced by the soil percentage coverage of the catchment area. The explained variation in plankton components (bacterio-, phyto- and zooplankton) and plankton size structure was determined by biological as well as morphometrical and geographical variables. Changes in the $\mathrm{Mg}^{2+}$ and $\mathrm{NO}_{3}-\mathrm{N}$ concentrations were traced over the period 19932001; the $\mathrm{Ca}^{2+}$ concentration, $\mathrm{pH}$, nutrients, bacterio-, phyto- and zooplankton were monitored in the period 1995-2001. A nutrient decrease accompanied by an increase in size of zooplankton organisms in the period 1995-2001 led to a considerable increase of water transparency in the lakes.
\end{abstract}

Key words: water chemistry, phytoplankton, zooplankton, bacterioplankton

\section{INTRODUCTION}

There are over 140 lakes of glacial origin in the Rila Mountains. The morphology, chemistry and biology of the lakes began to be studied in the thirties of last century. The first extensive quantitative research in the pelagial of some of these lakes was carried out in the period 1993-1995 as part of a French-Bulgarian project (Stoyanova et al. 1995, Botova et al. 1996). The Seven Rila Lakes were studied in the period 1995-1996 under a project financed by the Bulgarian National Fund for Scientific Research. The results relating to water chemistry (including nutrients), phytoplankton and zooplankton were published by Botev (2000), Beshkova (2000) and Naidenow \& Beshkova (2000), respectively. The high mountain lake ecosystems were further studied in the period 2000-2001 as part of the EMERGE project (European Mountain lake Ecosystems: Regionalisation diaGnostics \& socio-economic Evaluation).

The goal of the present study was to analyze the ecological relationships in the pelagial of the lakes, based on geographic, geological, morphometric, chemical and biological (plankton, fishes) data, and to evaluate the changes which occurred in some of the lakes during the 6-8 years of the study.

\subsection{Description of lakes}

Three groups of lakes located above the timberline in different regions (cirques) of the mountains were studied. Four of the Seven Rila Lakes were considered in the investigations (Okoto - RI0008, Bubreka -
RI0009, Sulzata - RI0010, Bliznaka - RI0011). They are all located in the northwestern part of the mountains. The two other groups, Mousala Lakes (Alekovo RI0067, Ledeno - RI0070, Karakashevo - RI0071) and Maritsa Lakes (Dolno Marichino - RI0075, Gorno Marichino - RI0076) are situated in the eastern part of the mountains (Tab. 1). The codes of the lakes are the same as those used in the EMERGE project.

The lake shores are stony, gravel and sandy, or covered with a thin soil layer, overgrown with grass and juniper. The lakes are popular tourist sites. Grazing by sheep and other animals was observed only in the region of the Seven Rila Lakes. The lakes have been stocked regularly for 30 years, more intensively in the past, with brown trout (Salmo trutta fario Linnaeus) and brook trout (Salvelinus fontinalis Mitchill). European minnow (Phoxinus phoxinus Linnaeus) has also been found.

\section{METHODS}

The data on the catchment area and morphology of the lakes were taken from Ivanov et al. (1964). The data on the soil percentage cover of the lake catchments were taken from remote sensing analysis within the EMERGE project.

Anthropogenic influence was estimated by means of a subjective scale (1-low, 2-moderate, 3-high), reflecting the frequency of tourist visits and presence of animals (sheep, horses, cattle) in the lake catchment.

The hydraulic retention time was estimated in two ways: by calculating the ratio between catchment area and lake surface area, and by calculations based on 
Tab. 1. Geography, morphology and catchment characteristics of the Rila Mountains Lakes studied. *Data after Ivanov et al. 1964; $\mathrm{RT}_{\text {estim }}=$ estimated retention time from approximate average precipitation and evaporation (Koleva 1991, Kyuchoukova 1991); $\mathrm{RT}_{\text {area }}=$ estimated retention time by the ratio between lake and catchment areas; MMS = Mountain meadow soils; MTS = Mountain toust soils; Anthr. infl. = anthropogenic influence (1-low, 2-moderate, 3-high).

\begin{tabular}{|c|c|c|c|c|c|c|c|c|c|}
\hline \multirow{2}{*}{$\begin{array}{l}\text { Lake group } \\
\text { Lake code }\end{array}$} & \multicolumn{4}{|c|}{ Seven Rila lakes } & \multicolumn{3}{|c|}{ Mousala lakes } & \multicolumn{2}{|c|}{ Maritsa lakes } \\
\hline & RI0008 & RI0009 & RI0010 & RI0011 & RI0067 & RI0070 & RI0071 & RI0075 & RI0076 \\
\hline \multicolumn{10}{|l|}{ Geography \& morphometry } \\
\hline Latitude N (degrees) & 42.19964 & 42.20556 & 42.19750 & 42.20122 & 42.19025 & 42.18206 & 42.19345 & 42.16413 & 42.16114 \\
\hline Longitude E (degrees) & 23.30584 & 23.30678 & 23.31028 & 23.31497 & 23.58314 & 23.589060 & 23.59060 & 23.59607 & 23.59615 \\
\hline Altitude (m a.s.l.)* & 2440 & 2282 & 2535 & 2243 & 2545 & 2709 & 2391 & 2368 & 2378 \\
\hline Mean depth (m)* & 12.5 & 13.7 & 2.1 & 6.5 & 5.7 & 5.4 & 3.1 & 1.8 & 4.3 \\
\hline Maximum depth $(\mathrm{m})^{*}$ & 37.5 & 28.0 & 4.5 & 27.5 & 14.5 & 16.4 & 6.6 & 5.5 & 10.8 \\
\hline Water volume $\left(10^{3} \mathrm{~m}^{3}\right)^{*}$ & 860 & 1170 & 15 & 590 & 135.5 & 97 & 80.5 & 20 & 92.3 \\
\hline Water surface $(\mathrm{ha})^{*}$ & 6.80 & 8.50 & 0.70 & 9.10 & 2.39 & 1.80 & 2.62 & 1.09 & 2.15 \\
\hline \multicolumn{10}{|l|}{ Catchment environment } \\
\hline Catchment area (ha)* & 36 & 56 & 18 & 210 & 68 & 20 & 110 & 150 & 110 \\
\hline $\mathrm{RT}_{\text {estim }}$ (years) & 2.70 & 2.40 & 0.09 & 0.33 & 0.23 & 0.54 & 0.08 & 0.02 & 0.10 \\
\hline $\mathrm{RT}_{\text {area }}$ (rel. units) & 0.19 & 0.15 & 0.04 & 0.04 & 0.04 & 0.09 & 0.02 & 0.01 & 0.02 \\
\hline MMS $(\%)$ & 0 & 0 & 0 & 0 & 100 & 100 & 100 & 100 & 100 \\
\hline MTS (\%) & 100 & 100 & 100 & 100 & 0 & 0 & 0 & 0 & 0 \\
\hline Soil percentage cover & 77.1 & 95.3 & 82.4 & 87.0 & 18.7 & 8.6 & 31.9 & 64.3 & 58.6 \\
\hline Granites $(\%)$ & 80 & 80 & 100 & 95 & 100 & 100 & 100 & 100 & 100 \\
\hline Gnaisses (\%) & 0 & 10 & 0 & 5 & 0 & 0 & 0 & 0 & 0 \\
\hline Amphibolites (\%) & 20 & 10 & 0 & 0 & 0 & 0 & 0 & 0 & 0 \\
\hline Anthr.infl. (rel. units) & 2 & 3 & 2 & 3 & 2 & 2 & 3 & 1 & 1 \\
\hline
\end{tabular}

evaporation data for previous years (Kyuchoukova 1991) and mean precipitation data relating to the Mousala Peak (Koleva 1991).

All samplings and measurements were taken in the deepest part of the lakes, during the autumn overturn of years 2000 and 2001 according to the unified sampling methods of the EMERGE project. Some general recommendations published by Straškrabová et al. (1999a) were also followed. The zooplankton samples were collected with several net hauls from the bottom to the surface. The chemical samples were taken from the surface. Bacterioplankton, phytoplankton and chlorophyll were collected with the top end of the sampler $0.5 \mathrm{~m}$ below the surface in the lakes of $5 \mathrm{~m}$ depth or less. This was also performed in the deeper lakes during the complete mixing. When the deeper lakes were thermally stratified, bacterioplankton, phytoplankton and chlorophyll were sampled at a depth 1.5 times the Secchi disc reading, but not deeper than $0.5 \mathrm{~m}$ from the bottom.

All the chemical analyses were carried out according to the methods described by Mosello \& Wathne (1997) and Mosello et al. (1997) in the laboratory of the Institute of Zoology and Limnology - University of Innsbruck (Austria).

The chlorophyll- $a$ was filtered through GF/B Whatman glass fiber filters, extracted in acetone, measured with a spectrophotometer and calculated after Jeffrey \& Humphrey (1975). The biomasses of phytoplankton and zooplankton were measured with a microscope according to the generally applied routine methodologies. In order to ensure proper comparisons, all the plankton components (bacterio- phyto- and zooplankton) were presented in carbon units. Their biomasses were converted to carbon units according to Straškrabová et al. (1999a).

Fishes were caught by gill nets and traps. Data on fish species occurrence in the lakes based on official records of the Rila National Park and fish-farm authorities were also used. Fish species occurrence was indicated by categorical variables, i.e. their presence was noted by "1", their absence by "0" (Tab. 2).

The data of year 2000 were analyzed by the CANOCO statistical package for multidimensional analyses (Version 4.5). The multivariate analyses were carried out with chemical and biological (biomasses of bacterio-, phyto- and zooplankton and plankton size structure) variables, which were used in turn as response and explanatory variables. The temporal differences were tested by paired t-test. Spearman rank correlation was also applied.

\section{RESULTS}

\subsection{Geographical, geological, chemical and plankton data}

Data on geological composition, soil structure and coverage of the catchment area as well as the hydraulic retention time (RT) of the lakes are presented here for the first time (Tab. 1).

The chemical data (Tab. 2) show weak acidification in 1-2 lakes, with pH slightly below 6.0. In general, alkalinity and conductivity showed a strong positive correlation with $\mathrm{pH}$ (Fig. 1). It seems that natural alkalinity was able to compensate for the recent acid input from the atmosphere or other sources. Only Ledeno Lake (RI0070), which has the highest altitude, $\mathrm{pH}$ below 6.0 and alkalinity below $20 \mu \mathrm{eq} \mathrm{l}^{-1}$, seems to be endangered 
Tab. 2. Physical, chemical and biological variables in the pelagial of the Rila Mountain Lakes investigated in Autumn (September-October) of the year 2000. DN = total dissolved nitrogen; TP = total dissolved phosphorus; DRSi = dissolved reactive silica; $\mathrm{N} \mathrm{P}^{-1}=$ ratio between nitrogen and phosphorus; $\mathrm{B}_{\mathrm{zoo}} \mathrm{B}_{\text {phyto }}{ }^{-1}=$ ratio between biomass of zoo- and phytoplankton expressed as fresh weight; $\mathrm{B}_{\text {phyto }}, \mathrm{B}_{\text {zoo }}=$ converted to carbon units after Straškrabová et al. (1999a); AIV = average individual volume obtained by dividing fresh biovolume (biomass) through total number of individuals; ACV = average cell volume obtained by dividing fresh biovolume (biomass) through total number of cells; * - estimated Secchi depth values from the linear regression between chlorophyll values and Secchi depth of deep lakes; ** 1-presence, 0 -absence.

\begin{tabular}{|c|c|c|c|c|c|c|c|c|c|}
\hline \multirow{2}{*}{$\begin{array}{l}\text { Lake group } \\
\text { Lake code }\end{array}$} & \multicolumn{4}{|c|}{ Seven Rila lakes } & \multicolumn{3}{|c|}{ Mousala lakes } & \multicolumn{2}{|c|}{ Maritsa lakes } \\
\hline & RI0008 & RI0009 & RI0010 & RI0011 & RI0067 & RI0070 & RI0071 & RI0075 & RI0076 \\
\hline \multicolumn{10}{|l|}{ Physico \& chemical variables } \\
\hline Temperature $\left({ }^{\circ} \mathrm{C}\right)$ & 10.0 & 10.0 & 10.5 & 12.5 & 12.0 & 10.0 & 10.0 & 10.0 & 10.0 \\
\hline Secchi depth (m) & 17.0 & 13.0 & $13.1 *$ & 12.5 & 11.0 & 14.5 & $11.4^{*}$ & $13.3^{*}$ & $13.3^{*}$ \\
\hline $\mathrm{pH}$ & 7.18 & 6.62 & 6.98 & 6.82 & 6.01 & 5.89 & 6.25 & 6.57 & 6.50 \\
\hline Conductivity $\left(\mu \mathrm{S} \mathrm{cm}^{-1} 25^{\circ} \mathrm{C}\right)$ & 25.9 & 25.8 & 35.3 & 32.5 & 13.3 & 12.4 & 17.0 & 21.6 & 20.5 \\
\hline $\mathrm{NH}_{4}-\mathrm{N}\left(\mu \mathrm{gN} 1^{-1}\right)$ & 1 & 1 & 3 & 2 & 2 & 2 & 1 & 105 & 19 \\
\hline $\mathrm{Ca}^{2+}\left(\mathrm{mg} \mathrm{l}^{-1)}\right.$ & 2.93 & 3.31 & 2.58 & 4.13 & 1.29 & 1.48 & 1.84 & 2.62 & 2.49 \\
\hline $\mathrm{Mg}^{2+}\left(\mathrm{mg} \mathrm{l}^{-1}\right)$ & 0.28 & 0.33 & 0.36 & 0.38 & 0.13 & 0.36 & 0.43 & 0.14 & 0.13 \\
\hline $\mathrm{Na}^{+}\left(\mathrm{mg} \mathrm{l}^{-1}\right)$ & 0.85 & 0.63 & 1.81 & 1.09 & 0.51 & 1.92 & 2.05 & 0.93 & 0.70 \\
\hline $\mathrm{K}^{+}\left(\mathrm{mg} \mathrm{l}^{-1}\right)$ & 0.63 & 0.31 & 0.60 & 0.47 & 0.11 & 0.32 & 0.26 & 0.28 & 0.29 \\
\hline Alkalinity $\left(\mu\right.$ eq $\left.1^{-1}\right)$ & 115.4 & 139.4 & 94.3 & 208.5 & 22.4 & 12.6 & 54.6 & 102.8 & 79.9 \\
\hline $\mathrm{SO}_{4}^{2-}\left(\mathrm{mg} \mathrm{l}^{-1}\right)$ & 3.78 & 2.95 & 4.46 & 2.99 & 2.23 & 2.82 & 3.29 & 2.83 & 2.63 \\
\hline $\mathrm{NO}_{3}-\mathrm{N}\left(\mu \mathrm{gN} 1^{-1}\right)$ & 58 & 0 & 0 & 46 & 109 & 210 & 63 & 0 & 18 \\
\hline $\mathrm{Cl}^{-}\left(\mathrm{mg} \mathrm{l}^{-1}\right)$ & 0.33 & 0.37 & 2.07 & 0.32 & 0.54 & 3.07 & 3.21 & 0.71 & 0.43 \\
\hline $\mathrm{DN}\left(\mu \mathrm{gN} 1^{-1}\right)$ & 182 & 149 & 189 & 244 & 285 & 402 & 235 & 390 & 295 \\
\hline $\mathrm{PO}_{4}-\mathrm{P}\left(\mu \mathrm{gP} 1^{-1}\right)$ & 3.8 & 4.1 & 8.5 & 5.0 & 2.5 & 2.2 & 8.2 & 4.8 & 1.5 \\
\hline $\mathrm{TP}\left(\mu \mathrm{gP}^{-1}\right)$ & 7.1 & 14.7 & 17.6 & 7.1 & 4.7 & 5.0 & 10.9 & 9.1 & 6.8 \\
\hline DRSi $\left(\mathrm{mg} \mathrm{Si}{ }^{-1}\right)$ & 1.26 & 0.84 & 0.72 & 1.20 & 0.71 & 0.82 & 1.40 & 1.95 & 1.65 \\
\hline $\mathrm{N} \mathrm{P}_{\text {total }}^{-1}$ (rel. units) & 57.0 & 22.0 & 23.0 & 77.0 & 126.0 & 178.0 & 47.0 & 96.0 & 93.0 \\
\hline $\mathrm{N} \mathrm{P}_{\text {inorg }}^{-1}$ (rel. units) & 34.0 & 0.5 & 12.5 & 1.3 & 98.0 & 213.0 & 17.2 & 17.0 & 15.5 \\
\hline \multicolumn{10}{|l|}{ Biological variables } \\
\hline Chlorophyll- $a\left(\mathrm{mg} \mathrm{m}^{-3}\right)$ & 0.48 & 1.52 & 2.30 & 13.14 & 1.12 & 0.53 & 7.34 & 2.03 & 2.06 \\
\hline $\mathrm{B}_{\text {bact }}\left(\mathrm{mgC} \mathrm{\textrm {m } ^ { - 3 } )}\right.$ & 19.70 & 26.40 & 23.20 & 36.10 & 29.20 & 26.00 & 31.87 & 1.05 & 1.03 \\
\hline $\mathrm{B}_{\text {phyto }}\left(\mathrm{mgC} \mathrm{m}^{-3}\right)$ & 12.00 & 10.40 & 11.40 & 230.40 & 16.40 & 7.20 & 331.60 & 5.60 & 119.80 \\
\hline $\mathrm{B}_{\mathrm{zoo}}\left(\mathrm{mgC} \mathrm{m} \mathrm{m}^{-3}\right)$ & 46.85 & 115.85 & 25.90 & 46.05 & 77.85 & 68.35 & 4.00 & 36.00 & 9.00 \\
\hline $\mathrm{B}_{\text {zoo }} \mathrm{B}_{\text {phyto }}^{-1}$ (rel. units) & 15.60 & 44.60 & 9.10 & 0.80 & 14.10 & 38.00 & 0.05 & 25.70 & 0.30 \\
\hline $\mathrm{ACV}_{\text {bact }}\left(\mu \mathrm{m}^{3}\right.$ cell $\left.^{-1}\right)$ & 0.093 & 0.080 & 0.095 & 0.098 & 0.117 & 0.096 & 0.318 & 0.95 & 0.112 \\
\hline $\operatorname{ACV}_{\text {phyto }}\left(\mu \mathrm{m}^{3}\right.$ cell $\left.^{-1}\right)$ & 3000 & 2600 & 136 & 472 & 1025 & 37 & 760 & 280 & 1000 \\
\hline $\operatorname{AIV}_{\text {zoo }}\left(10^{6} \mu \mathrm{m}^{3}\right.$ ind $\left.^{-1}\right)$ & 78.6 & 146.0 & 4.7 & 65.9 & 132.7 & 88.6 & 10.6 & 193.8 & 34.3 \\
\hline S. fontinalis & $1 * *$ & 0 & 0 & 0 & 1 & 0 & 1 & 0 & 0 \\
\hline S. truttaf. & $0 * *$ & 1 & 0 & 1 & 0 & 1 & 1 & 1 & 1 \\
\hline Ph. phoxinus & 0 & 1 & 0 & 1 & 0 & 0 & 0 & 1 & 1 \\
\hline
\end{tabular}

by acidification. According to Honsig-Erlenburg \& Psenner (1986), low alkalinity lakes in the Alps were more susceptible to acid impact. High $\mathrm{Cl}^{-}$and $\mathrm{NO}_{3}-\mathrm{N}$ concentrations were found in the high altitude lakes (Tab. 2). Both ions might derive from precipitation, but this cannot definitely be confirmed or refuted, due to the lack of chemical analysis of atmospheric deposition. The pooled $\mathrm{pH}$ data from 2000 and 2001 correlated (rank correlation after Spearman) significantly and negatively with $\mathrm{NO}_{3}-\mathrm{N}\left(\mathrm{R}_{\mathrm{Sp}}=-0,70 \mathrm{P}=0,001\right)$, and positively with $\mathrm{SO}_{4}{ }^{2-}\left(\mathrm{R}_{\mathrm{Sp}}=0,672 \mathrm{P}=0,0023\right)$, and did not correlate with $\mathrm{Cl}^{-}$concentrations.

The total dissolved nitrogen (DN) to total dissolved phosphorus (TP) ratio shows that some of the lakes were not strongly phosphorus limited. Moreover, the soluble inorganic nitrogen and phosphorus components show a $\mathrm{N} \mathrm{P}^{-1}$ ratio varying from an optimal condition to a nitrogen limitation for phytoplankton in some lakes (Tab. 2). The presentation of the three components (bacterio-, phyto- and zooplankton) in carbon units enabled a reliable comparison to be made between them.
In two of the lakes phytoplankton biomass prevailed with Asterionella formosa Hassall as dominant species (RI0011) and Coenococeus sp., Peridinium sp., Cryptomonas sp. as most abundant species (RI0071). In the other lakes the most abundant component was zooplankton, dominated by Daphnia rosea Sars (in RI0009) together with nauplii and Polyarthra dolichoptera Idelson (in two Mousala Lakes - RI0067, RI0070)

\subsection{Multivariate analysis of pelagic data}

Chemical data were analyzed first as response variables by RDA. The soil percentage cover of the catchment area was the only variable which could be evaluated as an explanatory variable. It explained about 39\% of the variance and was correlated positively with $\mathrm{pH}$ and phosphorus, and negatively with nitrogen (Fig. 1). Kopáčeck et al. (2000) described the same influence of soil percentage cover on nutrients for the Tatra Mountains Lakes.

The variables characterizing the bacterio-, phytoand zooplankton components as response variables were 


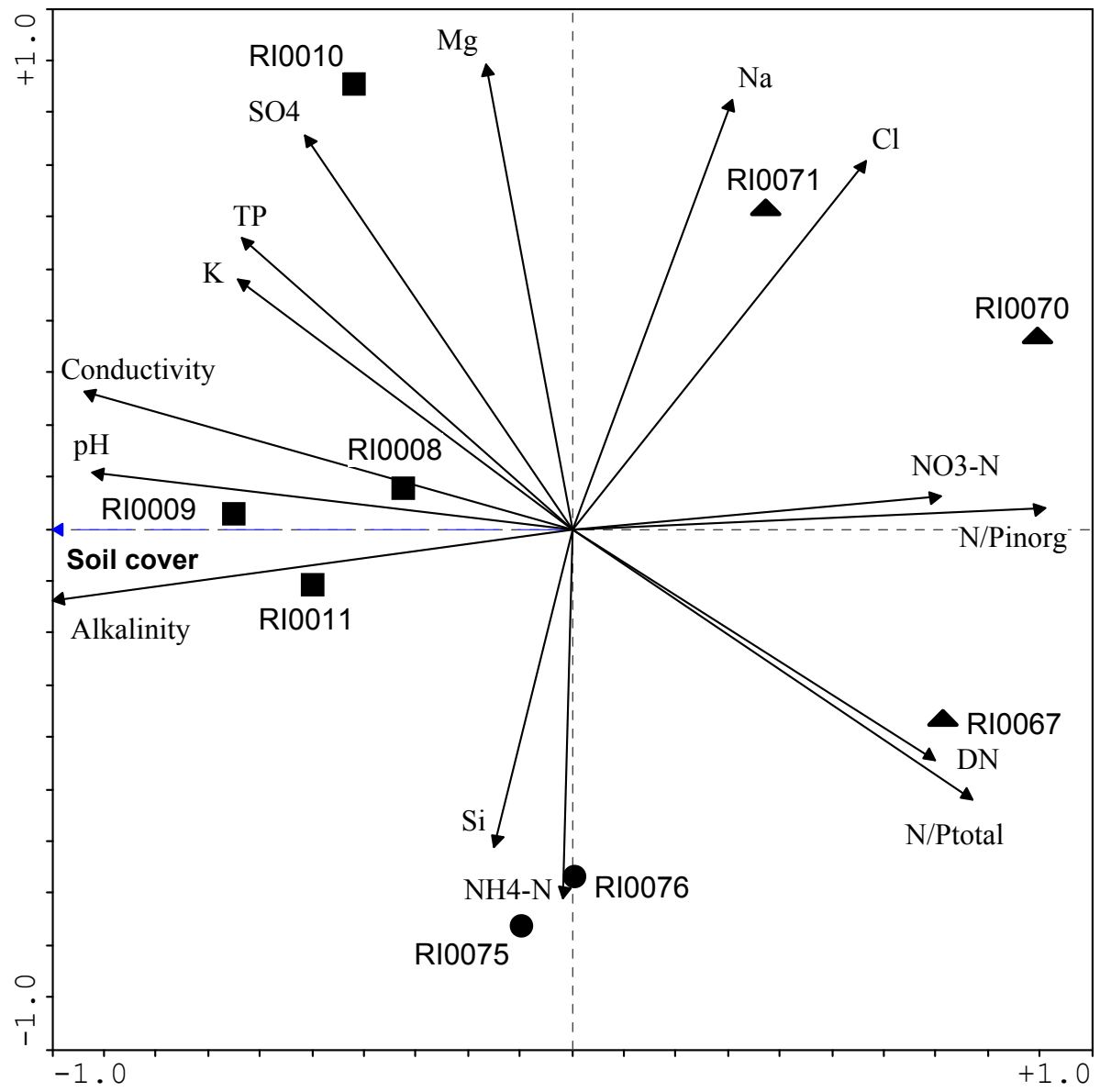

Fig. 1. Variable correlation and lake ordination triplot with chemical variables as response variables and soil percentage cover as explanatory variable, obtained by RDA. $\boldsymbol{\square}=$ Seven Rila lakes; $\boldsymbol{\Delta}=$ Mousala lakes; $\bullet=$ Maritsa lakes.

compared with all other available data, because topdown and bottom-up influences along the food chain in such oligotrophic aquatic ecosystems could not be excluded in advance. The RDA analysis delivered two significant explanatory variables (Fig. 2). D. rosea was the zooplankton species which determined a high zooplankton biomass and high transfer efficiency through the food web in three of the lakes (RI0009, RI0067, RI0070). On the opposite side we found the phytoplankton rich lakes (RI0011, RI0071). Anthropogenic influence seemed to be one of the reasons for the development of bacterioplankton. The percentage of variance explained was high $(66.5 \%)$ and was partitioned in favor of D. rosea $(63 \%)$. The rest of the variance $(37 \%)$ was related to anthropogenic influence. This was further evidence that the top-down influence in such lakes might be important or even prevail.

Figure 3 shows that the mean depth of the lakes and the occurrence of Schroederia setigera (Schrank) Lemmermann were the two explanatory variables accounting for $64.1 \%$ of the total variance related to the average size of bacterio-, phyto- and zooplankton organisms. The size of the three plankton components were presented in different ways: bacterio- and phytoplankton were described using the average cell size (biomass or volume, ACV). For zooplankton the average individual size (biomass or volume AIV) was given.

All the lakes with the exception of RI0075 were arranged along the first main axis according to their mean depth. The $A C V_{\text {phyto }}$ and $\mathrm{AIV}_{\text {zoo }}$ correlated with the first axis and with the mean-depth-gradient. On the other hand bacterial size correlated with the abundance of $S$. setigera. Both explanatory variables accounted for approximately half of the explained variance, partitioned between the mean depth, with $52 \%$, and $\mathrm{S}$. setigera with $48 \%$.

\subsection{Temporal changes}

\subsubsection{Temporal comparison of chemical data}

The temporal comparison was based on published data for the periods 1993-1995 and 1995-1996, and original EMERGE data for the period 2000-2001. Only the chemical data from the first period referred to all nine investigated lakes, while the data from the 19951996 period were restricted to the group of the Seven Rila Lakes. The sampling and analytical methodologies applied during the three periods differed considerably. 


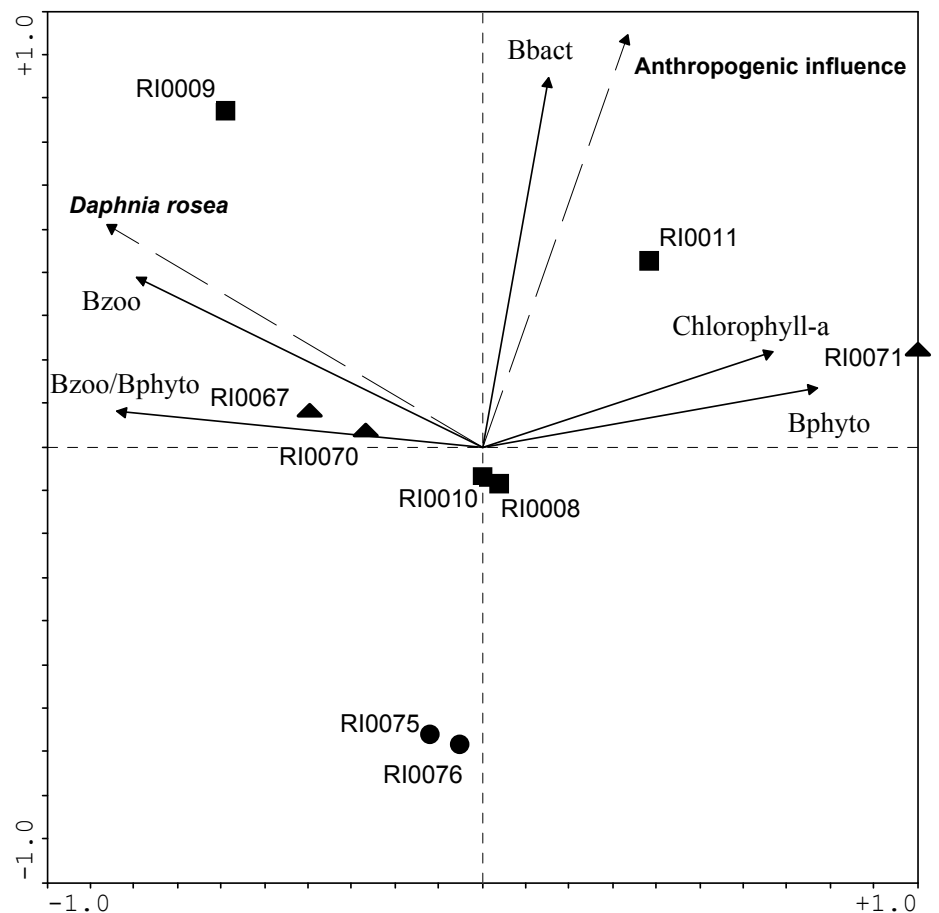

Fig. 2. Variable correlation and lake ordination triplot with biomass of bacteria $\left(\mathrm{B}_{\text {bact }}\right)$, phytoplankton $\left(\mathrm{B}_{\text {phyto }}\right)$, zooplankton $\left(\mathrm{B}_{\text {zoo }}\right)$ and ratio $\mathrm{B}_{\text {zoo }} \mathrm{B}_{\text {phyto }}{ }^{-1}$ as response variables and Daphnia rosea and Anthropogenic influence as explanatory variables, obtained by RDA. $\boldsymbol{\square}=$ Seven Rila lakes; $\boldsymbol{\Delta}=$ Mousala lakes; $\bullet=$ Maritsa lakes.

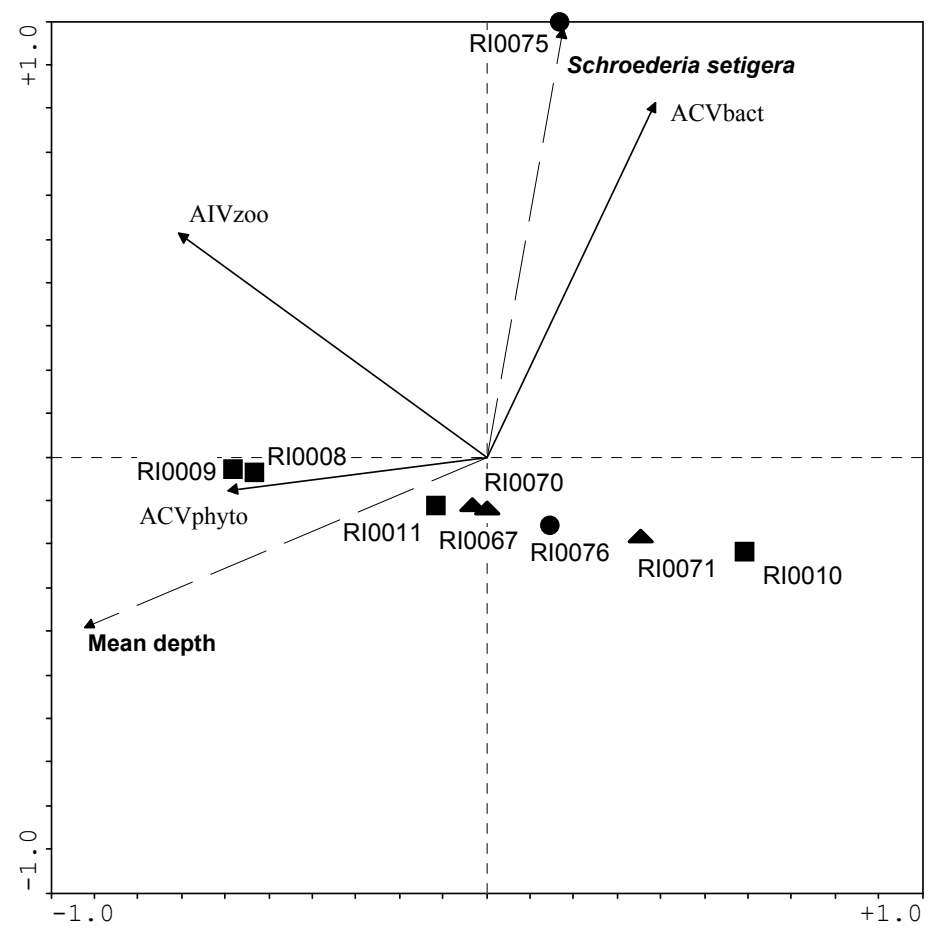

Fig. 3. Variable correlation and lake ordination triplot with average cell volume of bacteria $\left(A C V_{\text {bact }}\right)$ and phytoplankton $\left(A C V_{\text {phyto }}\right)$ and average individual volume of zooplankton $\left(\mathrm{AIV}_{\mathrm{zoo}}\right)$ as response variables and Mean depth and Schroederia setigera as explanatory variables, obtained by RDA. $\mathbf{m}=$ Seven Rila lakes; $\boldsymbol{\Delta}=$ Mousala lakes; $\bullet=$ Maritsa lakes. 

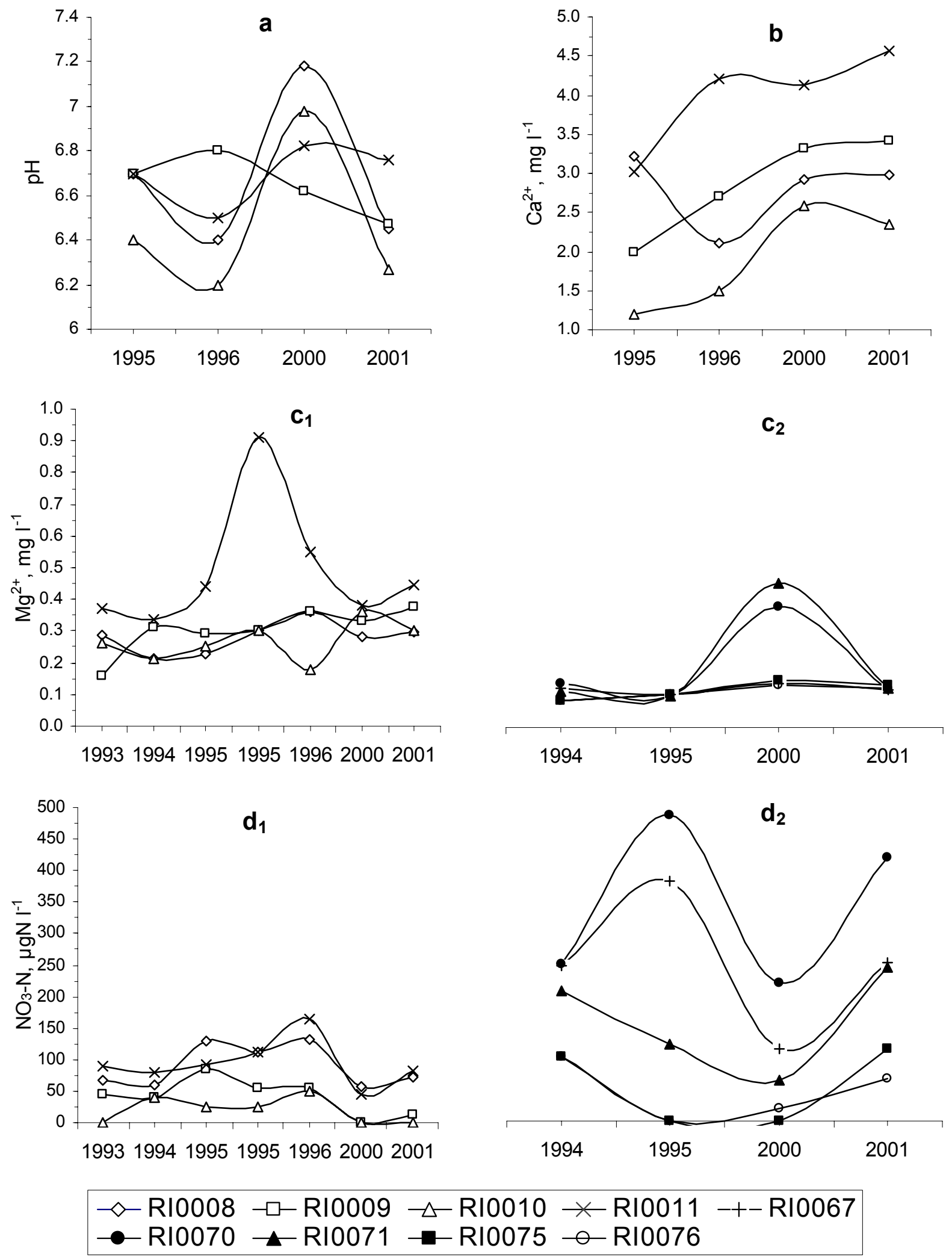

Fig. 4. Changes in some chemical variables in the pelagial of the high mountain lakes in the Rila Mountains during the period 19932001. $\mathrm{Mg}^{2+}$ and $\mathrm{NO}_{3}-\mathrm{N}$ presentations were divided into two parts $\left(\mathrm{c}_{1}, \mathrm{c}_{2}, \mathrm{~d}_{1}, \mathrm{~d}_{2}\right)$ because lakes RI0067, RI0070, RI0071, RI0075 and RI0076 were not sampled in 1993 and 1996, so that their combined presentation with other lakes would give an incorrect picture. 
The 1993-1995 samples were taken from the surface at a distance of $2 \mathrm{~m}$ from the lakeshore and all ions were analyzed by ion chromatography. During the 1995-1996 period the samples were taken at the deepest point of the lakes, as they were in 2000-2001. In the former period the water chemistry was analyzed by classical methods titration of $\mathrm{Ca}^{2+}, \mathrm{Mg}^{2+}$, colorimetric determination of $\mathrm{pH}, \mathrm{NO}_{3}-\mathrm{N}, \mathrm{PO}_{4}-\mathrm{P}$ (Botev 2000). Within the EMERGE project, $\mathrm{NH}_{4}-\mathrm{N}, \mathrm{TP}, \mathrm{PO}_{4}-\mathrm{P}$ and $\mathrm{DRSi}$ were analyzed colorimetrically; alkalinity was determined by Gran titration and all other ion concentrations by ion chromatography.

In 1995 four lakes were sampled almost simultaneously by the same research teams as those of the first two periods, which offered an opportunity for comparing methods applied and results. However, only $\mathrm{Mg}^{2+}$ and $\mathrm{NO}_{3}-\mathrm{N}$ concentrations from the first two periods delivered similar values in that year. The third period also revealed similar values and proportions between the lakes for both ions (Figs 4c1, 4c2, 4d1 and 4d2). The variations of $\mathrm{Mg}^{2+}$ over the years were small, sometimes even smaller than the differences between the lakes or lake groups. Probably the major factor affecting $\mathrm{Mg}^{2+}$ concentration in the Rila Lakes was the geology of their bedrock.

Geology might have the same affect on $\mathrm{Ca}^{2+}$, which showed small variations during the last two periods. The period 1993-1995 was omitted in figure 4b, because $\mathrm{Ca}^{2+}$ concentrations were 4 to 10 times lower. The small $\mathrm{Ca}^{2+}$ changes in years 2000 and 2001 were coupled negatively with $\mathrm{pH}$. The year 2000 was extremely dry and had significantly higher $\mathrm{pH}$ values than 2001, probably due to high radiation and temperature, leading to high photosynthetic activity. As a consequence, the carbonate equilibrium led to lower $\mathrm{Ca}^{2+}$ concentrations in all nine lakes in 2000. Three of the four lakes showed a similar tendency in the $1995-1996$ period, in which 1995 was represented by summer samples and 1996 by autumn samples (Fig. 4b). The comparison between the periods did not show the same relation between $\mathrm{pH}$ and $\mathrm{Ca}^{2+}$, probably due to discrepancies in methodology.

A direct comparison of $\mathrm{NO}_{3}-\mathrm{N}$ values measured in 1995 within the first two projects showed good similarity between them. The four lakes of the group of Seven Rila Lakes showed a slight maximum in 1995-1996 and a minimum in 2000-2001. The highest $\mathrm{NO}_{3}-\mathrm{N}$ values were observed in the Mousala Lakes, two of which are characterized by the highest altitudes. The minimum in year 2000 might have determined the recorded nitrogen limitation, as discussed previously.

\subsubsection{Temporal comparison of nutrient and biological data}

Since no data were available on such important elements as phosphorus and silica for the period 19931995 , they could be compared only over a shorter period - from 1995 to 2001. The quantitative phyto- and zoo- plankton data for 1995-1996 were published by Beshkova (2000) and Naidenow \& Beshkova (2000), respectively, and were obtained by practically the same methods as in 2000-2001. The year 1995 was represented only by summer samplings and 1996 only by autumn samplings.

The paired $t$-test showed that both total soluble phosphorus and phosphate phosphorus did not change in 1995-1996, but decreased significantly after 1996 (Figs $5 \mathrm{a}$ and $5 \mathrm{~b}$ ). A similar tendency has already been described for $\mathrm{NO}_{3}-\mathrm{N}$, for which significant differences were found in four of the Seven Rila Lakes in the 19962000 and 1996-2001 comparisons. The DRSi concentration showed the same decreasing tendency from 1996 to 2001 (Fig. 5c). However, a statistically significant difference was detected only in 1996-2001 $(\mathrm{P}=0.027)$.

This evident nutrient decrease was strongly supported by a higher average individual size of zooplankton (Fig. 5d) in years 2000 and 2001. In 2000 in particular the $\mathrm{AIV}_{\text {zoo }}$ (calculated from data of Naidenow \& Beshkova 2000) was higher than in 1995 and 1996, and the difference between the two periods was significant $(\mathrm{P}=0.05)$. The same was found for the zooplankton biomass, whose natural logarithm values in 2000 were significantly higher than in 1996 according to a paired $t$ test. As a consequence the $\mathrm{B}_{\text {zoo }}$ and $\mathrm{B}_{\text {phyto ratio }}$ (calculated from data of Beshkova 2000, Naidenow \& Beshkova 2000) in three of the four lakes was considerably higher in years 2000 and 2001 than in 1995 and 1996. There was no significant change in this ratio, in chlorophyll- $a$ (unpublished data of R. Kalchev from years 1995 and 1996) and phytoplankton biomass (taken from Beshkova 2000) in the four lakes for the period 1995-1996-2000-2001 (Figs 5e, 5f and 5g).

The consequence of the combined bottom-up and top-down influence along the pelagic food web was a sharp increase in transparency as evaluated by Secchi disk in the three deep lakes after 1996 (Fig. 5h).

\section{DISCUSSION}

It is difficult to draw conclusions about the presence or absence of the remote atmospheric transport of nitrogen and sulfur oxide gases and about the origin of $\mathrm{Cl}^{-}$ ions and their relation to $\mathrm{Na}^{+}$, because of the lack of analysis of chemical compounds in atmospheric deposition. However, the relationships between $\mathrm{pH}, \mathrm{Cl}^{-}, \mathrm{NO}_{3}^{-}$ $\mathrm{N}$ and $\mathrm{SO}_{4}{ }^{2-}$ on the pooled data of years 2000 and 2001 gave some indirect insight. The strong correlation between $\mathrm{Cl}^{-}$and $\mathrm{Na}^{+}\left(\mathrm{R}_{\mathrm{Sp}}=0.56, \mathrm{P}=0.015\right)$, the lack of correlation between $\mathrm{Cl}^{-}$and $\mathrm{pH}$, and high $\mathrm{Cl}^{-}$values in high altitude lakes lead to the hypothesis that $\mathrm{Cl}^{-}$and $\mathrm{Na}^{+}$deriving from atmospheric input were of marine origin and had no influence on $\mathrm{pH}$. The positive relation between $\mathrm{pH}$ and $\mathrm{SO}_{4}{ }^{2-}$ shows that the sulfate ions did not contribute to acidification and did not come from precipitation but mostly from the weathering of rocks. 

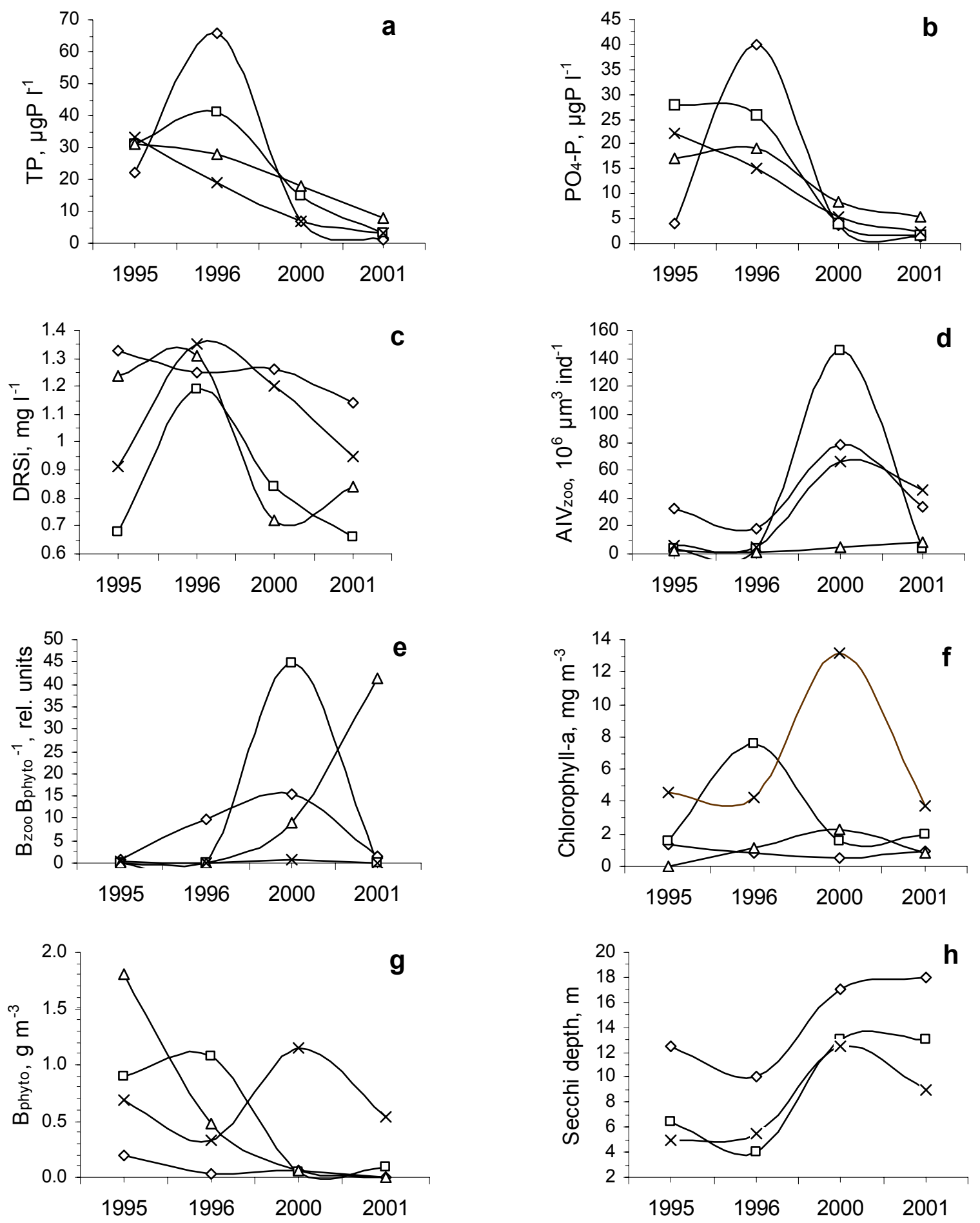

\section{$\neg$ RI0008 $\square-R I 0009 \neg$ RI0010 $\nsim$ RI0011}

Fig. 5. Changes in some chemical and biological variables in the pelagial of four high mountain lakes from the group of Seven Rila Lakes in the Rila Mountains during the period 1996-2001. 
If we consider the relation of $\mathrm{NO}_{3}-\mathrm{N}$ to $\mathrm{pH}$ and its altitude distribution, it can be concluded that the main source of nitrate is atmospheric deposition. Furthermore, nitrate is probably the major cause of the slight acidification of some of the Rila Lakes. The years 1995 and 2001 were distinguished by the highest nitrate concentrations.

The chemical data in figure 1 show that the percentage of soil coverage in the catchment area determined the nutrient concentration in the lakes. Kopáček et al. (2000) drew the same conclusion for a large number of lakes in the Tatra Mountains. Their results were much more convincing due to their considerably larger database. Phosphorus and nitrogen showed a strong negative correlation, while the $\mathrm{N} \mathrm{P}^{-1}$ ratio was closely correlated with and determined by nitrogen compound concentrations.

The substantial changes in $\mathrm{pH}$ reported for the period 1993-1995 (Stoyanova et al. 1995; Botova et al. 1996), from 5.0 (year 1993) to about 7.5 (1995), were of doubtful validity. We therefore considered only the $\mathrm{pH}$ values reported for the period between 1995 and 2001, which ranged from approximately 6.0 to 7.0 (Fig. 4a). Thus, despite low alkalinity values, results for this period did not reveal the occurrence of a substantial acid impact, in particular if we compare the $\mathrm{pH}$ values to those reported for other European lakes in the Alps (Honsig-Erlenburg \& Psenner 1986; Camarero et al. 1995) or in the Tatra Mountains (Fott et al. 1999; Kopáček et al. 2000). Only the RI0070 Ledeno Lake with its low alkalinity could be considered endangered. The low $\mathrm{NO}_{3}-\mathrm{N}$ concentrations and the drought in 2000 led to higher $\mathrm{pH}$ values than in 2001 .

The trophic status of the lakes can only be guessed at, in the absence of measured data. Considering the concentrations of total dissolved phosphorus and nitrogen (Tab. 2), there is a risk of overestimating the trophic status of the lakes, because these values reflect the potential rather than the realized productivity. According to Likens (1975), two lakes (RI0009, RI0010) in 2000 were in the meso-eutrophic range. This was confirmed by the OECD approach (Vollenweider \& Kerekes 1982), which also attributed the two lakes, on the basis of their TP content, with greatest probability to the mesotrophy class. However, the corresponding DN values were unambiguously within the ultraoligotrophic ranges, and the $\mathrm{N}^{-1}$ ratio values for inorganic compound indicated nitrogen limitation. A similar situation was observed in those lakes where the nitrogen concentration was in the most productive oligo-mesotrophic range (RI0067, RI0070, RI0075 and RI0076). The corresponding phosphorus values indicated the same or a lower trophic level. According to chlorophyll- $a$ and phytoplankton biomass, only two lakes (with different characteristics from RI0009, RI0010) were in the mesotrophic range (RI0011, RI0071). The rest of the lakes were described as oligotrophic on the basis of chloro- phyll values, or even ultraoligotrophic taking account of phytoplankton biomass values according to Likens (1975). Assuming the measured values of chlorophyll- $a$ as maxima, according to the OECD approach we can identify with greatest probability one mesotrophic lake (RI0011), one lake between meso- and oligotrophic (RI0071), four oligotrophic (RI0009, RI0010, RI0075, RI0076) and three ultraoligotrophic lakes (RI0008, RI0067, RI0070).

A further point to be discussed is the short, simple food web which usually characterizes mountain lakes (Callieri et al. 1999; Straškrabová et al. 1999b). In these oligotrophic aquatic ecosystems the top-down influence should prevail, according to McQueen et al. (1986). Our results of multivariate data analysis for the year 2000 and temporal changes in the period 1996-2001 showed that both bottom-up (nutrients, anthropogenic factor) and topdown $(D$. rosea $)$ influences occurred. If we assume that the variance partitioning (Figs 2 and 3) reliably represented the proportion between top-down and bottom-up variables, then each of them amounted to about $50 \%$.

The percentage of bacterial carbon with respect to total plankton carbon was very low $(0.8-2.5 \%)$ in the two Maritsa Lakes (RI0075, RI0076), despite their low productivity. The rest of the lakes (two of them mesotrophic) showed a bacterioplankton percentage ranging from 8.7 to $38.3 \%$, with lower values in the mesotrophic lakes and higher values in the oligotrophic one. This confirmed the thesis of Straškrabová et al. (2000) about the increased share of bacterioplankton in low productivity aquatic ecosystems.

Bacterioplankton of a size structure consisting of long bacterial filaments was accompanied by a similarly long-shaped phytoplankton species - Schroederia setigera as explanatory variable (Fig. 3).

Most probably the connection between long bacterial filaments and long S. setigera cells is to be found in their equally successful survival strategies, based on their similar shapes and relation to zooplankton feeding. Many studies dealt with the survival and intensive development of filamentous and other types of large algal colonies (e.g. blue-green algae) and related them to their resistance to grazing (Benndorff et al. 1988; Havens 1998; Kalchev et al. 2002).

\section{CONCLUSIONS}

All but two of the nine high mountain lakes investigated in the Rila Mountains were oligotrophic or ultraoligotrophic. Their nutrient concentrations and other dissolved chemical compounds were influenced by the percentage of soil coverage in their catchment areas. The lakes with less soil coverage and at high altitudes were distinguished by high nitrogen concentrations and low $\mathrm{pH}$ values, which are closely related to each other. Only the highest lake, characterized by the lowest alkalinity, was endangered by acidification, although with- 
out reaching alarming $\mathrm{pH}$ values. The tendency during the last 6-8 years has demonstrated a considerable nutrient decrease at least in four of the largest lakes. This was accompanied by an increase in zooplankton size and in biomass. Both bottom-up and top-down influences acted in the direction of increasing water column transparency, i.e. of an improvement in the water quality of the lakes investigated during the 1995-2001 period.

\section{ACKNOWLEDGMENTS}

This study was funded by the European Commission Framework Programme V within EMERGE project (European Mountain lake Ecosystems: Regionalisation diaGnostics \& socio-economic Evaluation - Project № EVK1-CT-1999-00032) and by the National Fund for Scientific Research, as Project B-1002/00.

In particular we want to thank to Prof. R. Psenner for giving us an opportunity to perform the chemical analyses in the Laboratory of Institute of Zoology and Limnology, University of Innsbruck (Austria) and to Ing. J. Franzoi and Ing. W. Müller for their help in the analyses of samples. We are also very grateful to Dr. V. Straškrabová from the Hydrobiological Institute in České Budejovice (Czech Republic) for bacterioplankton analysis, for her responsiveness, accurate and versatile help in all aspects concerning our collaboration within the EMERGE project. We would like to thank Dr Martin Kernan for his help with the numerical analysis.

The authors are grateful also to the Rila National Park authorities for the responsiveness and collaboration.

\section{REFERENCES}

Benndorff, J., H. Schulz., A. Benndorff, R. Unger, E. Penz, H. Kneschke, K. Kossatz, R. Dumke, U. Hornig, R. Kruspe \& S. Reichel. 1988. Food-web manipulation by enhancement of piscivorous fish stocks: long-term effects in the hypertrophic Bauzen Reservoir. Limnologica, 19 (1): 97-110.

Beshkova, M. 2000. The phytoplankton of the glacial high mountain lakes Sedemte Rilski Ezera (the Rila Mountains, Bulgaria). In: V. Golemansky, W. Naidenow (Eds). Biodiversity and Evolution of Glacial Water Ecosystems in the Rila Mountains. Institute of Zoology, Ministry of Environment and Waters, Sofia: 105-123.

Botev, I. 2000. Chemical composition and its vertical distribution in seven glacial high altitude lakes in the Rila Mountains (Southwestern Bulgaria). In: V. Golemansky, W. Naidenow (Eds). Biodiversity and Evolution of Glacial Water Ecosystems in the Rila Mountains. Institute of Zoology, Ministry of Environment and Waters, Sofia: 89103.

Botova, B., St. L. Tsakovski, I. B. Karadjova, G. Ch. Petkov, P. B. Mandjukov \& V. D. Simeonov. 1996. Hydrochemical and ecological situation in Rila and Pirin high-mountain lakes during 1995. In: Observatoire de Montangne de Moussala. OM2, Sofia 1996, 4, 94-112.

Callieri, Cr., A. Pugnetti \& M. Manca. 1999. Carbon partitioning in the food web of a high mountain lake: from bacteria to zooplankton. J. Limnol., 58: 144-151.

Camarero, L., J. Catalan, A. Boggero, A. Marchetto, R. Mosello \& R. Psenner. 1995. Acidification in high Mountain
Lakes in Central, Southwest and Southeast Europe (Alps, Pyrennees, Pirin). Limnologica, 25 (2): 141-156.

Fott, J., M. Blažo, E. Stuchlik \& O. Strunecký. 1999. Phytoplankton in three Tatra Mountain lakes of different acidification status. J. Limnol., 58: 107-116.

Havens, K.E. 1998. Size structure and energetics in a plankton food web. Oikos, 81: 346-358.

Honsig-Erlenburg, W. \& R. Psenner. 1986. Zur Frage der Versäurung von Hochgebirgsseen in Kärnten. Carinthia II 176/96. Jahrgang, Klagenfurt: 443-461.

Ivanov, K., A. Sotirov, A. Rozhdestvenski \& D. Vodenicharov. 1964. Ezerata v Bulgaria (Lakes in Bulgaria). Troudove na Institouta po Hidrologya i Meteorologiya (Works of the Institute of Hydrology and Meteorology, State's publisher "Science and Art", Sofia: 237 pp.

Jeffrey, S. W. \& G.F. Humphrey. 1975. New spectrophotometric equations for chlorophylls a, b, $\mathrm{cl}$ and $\mathrm{c} 2$ in higher plants, algae and natural phytoplankton. Biochem. Physiol., Pflanzen, 167: 191-194.

Kalchev, R.K., L.Z. Pehlivanov, \& M.B. Beshkova. 2002. Trophic relations in two lakes of the Bulgarian Black Sea coast and possibilities for their restoration. Wat. Sci. Tech., 46: $1-8$.

Koleva, E. 1991. Razpredelenie na valezhite (Precipitation distribution In: Iv. Stanev, M. Kyuchoukova, St. Lingova (Eds), Klimatut na Bulgaria (Climate of Bulgaria) Sofia, Publisher of Bulgarian Academy of Sciences: 225-237.

Kopáček, J., E. Stuchlik, V. Straškrabová \& P. Pšenáková. 2000. Factors governing nutrients status of mountain lakes in the Tatra Mountains. Freshwat. Biol., 43: 369-383.

Kyuchoukova, M. 1991. Soumarno izparenie (Total evaporation) In: Iv. Stanev, M. Kyuchoukova, St. Lingova (Eds.), Klimatut na Bulgaria (Climate of Bulgaria) Sofia, Publisher of Bulgarian Academy of Sciences: 252-258.

Likens, G.E. 1975. Primary production of inland aquatic ecosystems, In: H. Lieth \& R.H. Whittaker (Eds). Primary Productivity of the Biospere, Ecological Studies 14, Berlin, Heidelberg, NewYork, Springer Verlag: 185-202.

McQueen, D.J., J.R. Post \& E.L. Mills. 1986. Trophic relationships in freshwater pelagic ecosystems. Can. J. Fish. Aquat. Sci., 43: 1571-1581.

Mosello, R. \& B.M. Wathne., 1997. Surface water. Chemical analysis of major ions and nutrients. Analytical quality control. In: Wathne, B.M. (Ed.), MOLAR. Measuring and modeling the dynamic response of remote mountain lake ecosystem to environmental change: A programme of Mountain lake Research. MOLAR Project Manual. NIVA Report 0.96061: 24-45.

Mosello, R., B.M. Wathne \& S. Van der Berg, 1997. Surface water. Sampling and analysis protocol. In: Wathne, B.M. (Ed.), MOLAR. Measuring and modeling the dynamic response of remote mountain lake ecosystem to environmental change: A programme of Mountain lake Research. MOLAR Project Manual. NIVA Report 0-96061: 20-23.

Naidenow, W. \& M. Beshkova. 2000. Quantitative development and vertical distribution of plankton in Sedemte Ezera Lakes (the Rila Mountains, Bulgaria). In: V. Golemansky, W. Naidenow (Eds). Biodiversity and Evolution of Glacial Water Ecosystems in the Rila Mountains. Institute of Zoology, Ministry of Environment and Waters, Sofia: 137-153.

Stoyanova, K., P.B. Mandjukov, St.L. Tsakovski, M. Tchalakova, I.B. Karadjova, G. Gerov \& V.D. Simeonov. 1995. Hydrochemical and ecological characteristics of the high mountain lakes in Rila and Pirin In: Observatoire de Montange de Moussala. OM2, Sofia, 3: 75-86.

Straškrabová, V., C. Callieri, P. Carrillo, L. Cruz-Pizarro, J. Fott, P. Hartman, M. Macek, J.M. Medina-Sánchez, J. Nedoma \& K. Šimek. 1999a. Investigations on pelagic food webs in mountain lakes - aims and methods. $J$. Limnol., 58: 77-87. 
Straškrabová, V., K. Šimek, J. Nedoma. 1999b. Importance of pelagic bacteria in lakes and reservoirs of different trophy - implications for long-term monitoring, In: Book of $A b$ stracts, Sustainable Lake Management, 8-th International Conference on the Conservation and Management of Lakes. 17-21 May 1999, Copenhagen-Denmark, S7C-5.
Straškrabová, V., K. Šimek, M. Macek, P. Hartman, J. Fott \& M. Blažo. 2000. Pelagic food webs and microbial loop in low-alkalinity mountain lakes. Verh. int. Ver. Limnol., 27: 513-516.

Vollenweider R.A. \& J. Kerekas (Eds). 1982. Eutrophication of waters: Monitoring, assessment and control. OECD Paris. 